\title{
Wound Healing Gel Based on Chlorella vulgaris Extract Characterization
}

\author{
Alexsandra Andrade ${ }^{1}$, Micaleyde Egito ${ }^{2}$, Williana Vilela ${ }^{2}$, Romero Costa ${ }^{3}$, Pedro Neto ${ }^{2}$, Rosali Silva ${ }^{2}$, \\ Ana Porto ${ }^{1}$, Raquel Bezerra ${ }^{8, *(D)}$
}

1 Department of Morphology and Animal Physiology, Rural Federal University of Pernambuco, Av. Dom Manoel de Medeiros, s/n, Dois Irmãos - CEP: 52171-900 - Recife/PE, Brazil; alexsandrafrazao84@gmail.com (A.A.); ana.porto@ufrpe.br (A.P.); raquel.pbezerra@ufrpe.br (R.B.);

2 Department of Pharmaceutical Sciences, Federal University of Pernambuco, Av. Prof. Artur de Sá - Cidade Universitária, s/n, CEP: 50740-521 - Recife/PE, Brazil; micaleyde@gmail.com (M.E.); willianatorresvilela@hotmail.com (W.V.); pedro.rolimnt@ufpe.br (P.N.); rosali.silva@ufpe.br (R.S.);

3 Institute of Biological Sciences, University of Pernambuco, R. Arnóbio Marquês, 310, CEP: 50100-130 -Recife/PE, Brazil; romero_brandao@yahoo.com.br (R.C.)

* Correspondence: raquel.pbezerra@ufrpe.br (R.B.);

Scopus Author ID 16038638700

Received: 22.06.2021; Revised: 25.07.2021; Accepted: 28.07.2021; Published: 16.08.2021

\begin{abstract}
Chlorella vulgaris cell extract was used to develop wound-healing products by our research group. However, it is required to characterize this formulated for improved patient compliance and to reduce the force required to spread the product on the injured, painful and sensitive areas. Therefore, $C$. vulgaris extract was characterized by the presence of phytochemicals and proteins, the formulation was characterized in relation to organoleptic properties, $\mathrm{pH}$, and rheological profiles, while both cell extract and excipients of the formulation were analyzed by infrared spectroscopy and thermogravimetric (TGA). In the cell, extract contain $1.35 \pm 0.18 \mathrm{mg} / \mathrm{g}$ AG of total phenol content and $65.57 \mu \mathrm{g} \mathrm{mL}-1$ of one lectin of $36 \mathrm{kDa}$ with the hemagglutinating activity of $\geq 23$ for erythrocyte type $\mathrm{B}$. The formulation showed a green color, smooth texture, $\mathrm{pH}$ of $7.09 \pm 0.07$, suitable for skin injury and pseudoplastic behavior. The infrared showed the presence of amine, carbohydrates, and terpenes in the cell extract and the absence of chemical interaction between the cell extract and carbopol hydrogel. The formulation is very stable near room temperature. The results obtained will provide parameters for the production of inputs in the pharmaceutical industry, as well as for the quality control of intermediates and the finished product based on $C$. vulgaris.
\end{abstract}

Keywords: physicochemical properties; viscosity; wound healing.

(C) 2021 by the authors. This article is an open-access article distributed under the terms and conditions of the Creative Commons Attribution (CC BY) license (https://creativecommons.org/licenses/by/4.0/).

\section{Introduction}

Bioactive metabolites from microalgae are interesting in developing new products for the medical, pharmaceutical, cosmetic, and food industries [1,2]. The microalgae Chlorella vulgaris had a strong increase in applications in the last years due to their biochemical property [3]. Proteins and enzymes such as nitrate reductase, catalase, lectins, proteases, alkalases, and secondary metabolites such as flavonoids, saponins, tannins, phenolic compounds, and terpenes have been reported in Chlorella extracts [4,5]. Some studies with Chlorella spp. extract demonstrates several biological activities as antitumor activity, antioxidants, and wound healing [6,7]. 
Several factors can result in skin wounds such as fire, temperature, chemicals, diabetes [8]. Over the years, new methods for administering medicines are developed to overcome the limitations of conventional vehicles or optimize the administration of these products. Drugs for application on intact or damaged skin are presented in semisolid consistency, including ointments, cream, emulsions, and gels [9].

The formulations hydrogel-based supply all the necessary properties to control a moist, allowing gaseous exchange, protect lesions of microorganisms, non-toxic, and ability to deliver several molecules $[10,11]$ topically. Thus, a formulation acts as a barrier and should give rapid wound closure, reducing scar formation.

The physical and chemical stability of topical formulations must be determined to evaluate the quality of the product and must be kept constant during the formulation shelf-life. The stability of a formulation for topical use can be evaluated by rheological behavior, structural and morphological parameters. Furthermore, the performance of topical products depends to a great extent on the rheological behavior [12].

Bioactives can be as efficient as those produced by chemical synthesis, where the transformation of these compounds into a drug must ensure chemical and pharmacological integrity [13]. In this way, the use of biomolecules with therapeutic activity and applications in biotechnology obtained from microalgae can be a potential source in producing therapeutic healing agents. For this, it is necessary to know the molecules responsible for this biological action and define the possible phytopharmaceuticals that justify its great pharmaceutical and biotechnological potential. There is still a growing interest in studying and understanding how natural products can contribute to improving the characteristics. Therefore, this work aimed to characterize a topical formulation of a cell extract of $C$. vulgaris to activity wound healing.

\section{Materials and Methods}

\subsection{Microorganism and culture conditions.}

C. vulgaris (UTEX, 1803) was obtained from the University of Texas culture collection (Austin, TX). C. vulgaris was cultivated in Bold's Basal medium [14] supplemented with 1\% corn steep liquor [15], at room temperature $27 \pm 1{ }^{\circ} \mathrm{C}$, continuous light of $52 \pm 5 \mu \mathrm{mol}$ photons $\mathrm{m}^{-2} \mathrm{~s}^{-1}$ and aeration constant. After a stationary phase of cell growth had been reached, biomass was centrifuged at $340 \mathrm{xg}$ for 8 min (Sigma Laboratory Centrifuge 6-15, Osterode am Harz, Germany) and lyophilized (SP Scientific BenchTop Pro, Warminster, USA) for subsequent analysis.

\subsection{Preparation of the extract.}

The extract was prepared based on the methodologies of Chu et al. [4]. The extraction was performed at $50 \mathrm{mg} \mathrm{mL}^{-1}$ using $0.15 \mathrm{M}$ Tris-HCl-Saline buffer ( $\mathrm{pH} 7.5$ ), using ice bath sonication (Sonicator Bandelin electronic, Berlin, Germany) in 10 cycles of 1 min, interval of 1 min between each pulse. The material was centrifuged (Hermle Labortechnik Centrifugue $326 \mathrm{HK}$, Wehingen, Germany) at $820 \mathrm{xg}$ for $7 \mathrm{~min}$ at $4{ }^{\circ} \mathrm{C}$. The supernatant was used as cell extract for the experimental activities. 
2.4. Phytochemical characterization.

\subsubsection{Phytochemical screening.}

Phytochemical analysis of the extract was carried out using ethanol chemical solvent. The presence and absence of phytoconstituents such as alkaloids, terpenoids, steroids, tannins, saponins, flavonoids, phenols, coumarins, quinones, and glycosides were according to Savithramma et al. [16].

\subsubsection{Determination of total phenolic content.}

Total phenolic content was determined with Folin-Ciocalteu, and results were expressed as gallic acid equivalents ( $\mathrm{mg}$ of $\mathrm{GA} / \mathrm{g}$ of extract) [17]. A methanolic solution of $C$. vulgaris extract at $1 \mathrm{mg} \mathrm{mL}^{-1}$ was used in the analysis. The reaction mixture was prepared by mixing $0.5 \mathrm{~mL}$ of methanolic extract, $2.5 \mathrm{~mL}$ of $10 \%$ Folin-Ciocalteu's reagent dissolved in water, and $2.5 \mathrm{~mL}$ of $7.5 \%$ sodium bicarbonate. The sample was incubated at $45{ }^{\circ} \mathrm{C}$ for $45 \mathrm{~min}$, and the absorbance was measured at $765 \mathrm{~nm}$. Quantification was done based on a standard curve of gallic acid.

\subsection{Protein characterization.}

\subsubsection{Protein purification.}

Cell extract of $C$. vulgaris was precipitated with $60 \%$ ammonium sulfate, resuspended in $0.15 \mathrm{M}$ Tris-HCl-NaCl buffer $\mathrm{pH} 7.5$, and loaded on anion exchange chromatography using HiTrapTM DEAE FF column $(0.7 \times 2.5 \mathrm{~cm})$ (AKTA TM Avant 25, Uppsala, Sweden). Elution was performed at a flow rate of $1 \mathrm{~mL} \mathrm{~min}^{-1}$ with a linear gradient of $0.0-1 \mathrm{M} \mathrm{NaCl}$ in the same buffer. Fractions were collected and monitored at $280 \mathrm{~nm}$.

\subsubsection{Protein concentration.}

The protein content of the samples was estimated by the BCA protein assay reagent kit (BCATM Protein Assay Kit, Thermo SCIENTIFIC), according to the manufacturer's instructions. Serum albumin was used as the standard protein.

\subsubsection{Analysis of the extract in electrophoresis.}

SDS-PAGE gel was performed at $12.5 \%$ (w/v) according to Laemmli [18]. The protein bands were revealed by silver nitrate. The molecular protein markers were: Myosin from the porcine heart (200 kDa), $\beta$-Galactosidase from E. coli $(116 \mathrm{kDa})$, Phosphorylase b from rabbit muscle (97 kDa), Albumin (66 kDa), Glutamic Dehydrogenase from bovine liver (55 kDa), Ovoalbumin from chicken egg (45 kDa), Glyceraldehyde-3-phosphate Dehydrogenase from rabbit muscle $(36 \mathrm{kDa})$, Carbonic Anhydrase from bovine erythrocytes $(29 \mathrm{kDa})$ and Trypsinogen from bovine pancreas $(24 \mathrm{kDa})$.

\subsubsection{Hemagglutinating activity.}

The determination of hemagglutinating activity (HA) of purified fractions was performed in microtiter plates described by Correia and Coelho [19]. Fractions extracted (50 $\mu \mathrm{L}$ ) were twofold serially diluted with $0.15 \mathrm{M} \mathrm{NaCl}$, followed by the addition of a $50 \mu \mathrm{L}$ suspension of bovine, horses, or human erythrocytes (A, B, O blood type) treated with $2.5 \%$ 
(v/v) glutaraldehyde. After $45 \mathrm{~min}$, HA was expressed as the highest dilution exhibiting hemagglutination. Hemagglutination was observed macroscopically and expressed as a titer.

\subsection{Preparation of formulation.}

The formulation was prepared according to Melo et al. [7] and Porto et al. [20] with some adaptations. Carbopol-940 $(0.8 \% \mathrm{w} / \mathrm{w})$ was dissolved in distilled water, stirred until to obtain a clear solution, and slowly added methylisothiazolinone $(0.2 \% \mathrm{w} / \mathrm{w})$. The gel was kept overnight in a refrigerator to allow swelling in a closed glass container. After $24 \mathrm{~h}, 25 \% C$. vulgaris extract was added to the carbopol-940 gel with stirring to obtain a homogeneous mixture. The gel formulation was neutralized to $\mathrm{pH}$ 7.0-7.5 with triethanolamine.

\subsection{Formulation characterization.}

\subsubsection{Organoleptic evaluation.}

The gel formulation was analyzed for smell, homogeneity, color, and consistency by visual inspection.

\subsection{2. $\mathrm{pH}$ measurement.}

The $\mathrm{pH}$ of the gel formulation was measured using a digital $\mathrm{pH}$ meter (Quimis Q400AS, Diadema, São Paulo).

\subsubsection{Viscosity.}

The viscosity measurement was using Rheology International Viscometer (Ri:2: M $/ \mathrm{H} 1 / \mathrm{H} 2$, California, EUA) with spindle type S7, the rotation speed of 10 to $100 \mathrm{rpm}$ and 100 to $10 \mathrm{rpm}$ with a sample volume of $60 \mathrm{~mL}$ at temperature $18.0 \pm 0.5^{\circ} \mathrm{C}$.

\subsubsection{Spreadability.}

The spreadability of the formulation was based on a method proposed by Knorst [21]. The sample was introduced within a central orifice of $1.2 \mathrm{~cm}$ diameter premarked on a glass plate. A glass plate of known weight was placed over the sample was allowed to rest on the upper glass plate for $1 \mathrm{~min}$. This procedure was repeated successively, adding other plates in one-min intervals. The increase in the diameter after spreading the formulation was noted.

\subsection{Fourier-Transform Infrared Spectroscopy (FTIR).}

FTIR spectra of the cell extract, carbopol-940, and formulation were determined by infrared spectrophotometer (Spectrum 400 PerinElmer ${ }^{\circledR}$, Massachusetts, EUA) using a range of $650-4000 \mathrm{~cm}^{-1}$ with a resolution ratio of $4 \mathrm{~cm}^{-1}$, and the scan number was 16 .

\subsection{Thermogravimetric analysis (TGA).}

Thermal analysis of the cell extract, carbopol-940, and methylisothiazolinone was evaluated on thermogravimetric analyzer TGA (DTG-60H, Barueri, São Paulo) carried out under dynamic nitrogen atmosphere $\left(100 \mathrm{~mL} \mathrm{~min}^{-1}\right)$. These samples were heated from 30 to $600{ }^{\circ} \mathrm{C}$ at a heating rate of $10^{\circ} \mathrm{C} \mathrm{min}^{-1}$. 
2.10. Statistical analysis.

All analyses were performed in triplicate and expressed by means \pm standard deviation (SD).

\section{Results and Discussion}

\subsection{Phytochemical characterization.}

Phytochemical as terpenes, flavonoids, phenols, protein, and carbohydrates have beneficial actions on healing activity [7]. Qualitative analysis of phytochemicals and total phenols quantification showed the presence only of terpene e $1.35 \pm 0.18 \mathrm{mg} / \mathrm{g}$ of GA in $C$. vulgaris cell extract. It is well known that terpene plays a vital role to wound healing due their analgesic properties, anti-inflammatory, antifungal, antimicrobial activities [22-24], while that phenolic content has antioxidant activity [25]. The earlier study reports terpenes in C. vulgaris extracts and total phenols in higher values than this study. Dantas et al. [5] used C. vulgaris $(3.45 \pm 0.26 \mathrm{mg} / \mathrm{g})$, showing that the growth conditions are salinity, luminosity and nutrient availability, type of culture, autotrophic or heterotrophic, influence on total phenol contents of Chlorella microalgae.

\subsection{Protein characterization.}

Proteins, such as keratin, sericin, collagenase, and lectins, can contribute to wound healing through granulation tissue formation, keratinocyte migration, and fibroblast stimulation, with a consequent increase in collagen production [7, 25-27].

Cell extract was precipitated and eluted on a chromatographic column with two salt concentrations $(0.15 \mathrm{M}$ and $1.0 \mathrm{M})$. The analysis revealed the presence of two peaks (Figure 1). Only (PI) the first peak showed protein content of $65.57 \pm 0.005 \mu \mathrm{g} \mathrm{mL} \mathrm{L}^{-1}$, the molecular mass of $36 \mathrm{kDa}$ (Figure 2), and hemagglutinating activity $\geq$ to $2^{3}$ to human erythrocyte type $\mathrm{B}$. Melo et al. [7] reported the hemagglutinating activity of $C$. vulgaris mixotrophic extract with values of $\geq 2^{48}$ using rabbit erythrocytes and $\geq 2^{24}$ using type B human blood. These results demonstrate the presence of lectin that may have promoted tissue healing. Other studies showed that lectins increased collagen deposition and cutaneous appendages, reepithelialization, and reduces inflammation [28-30].

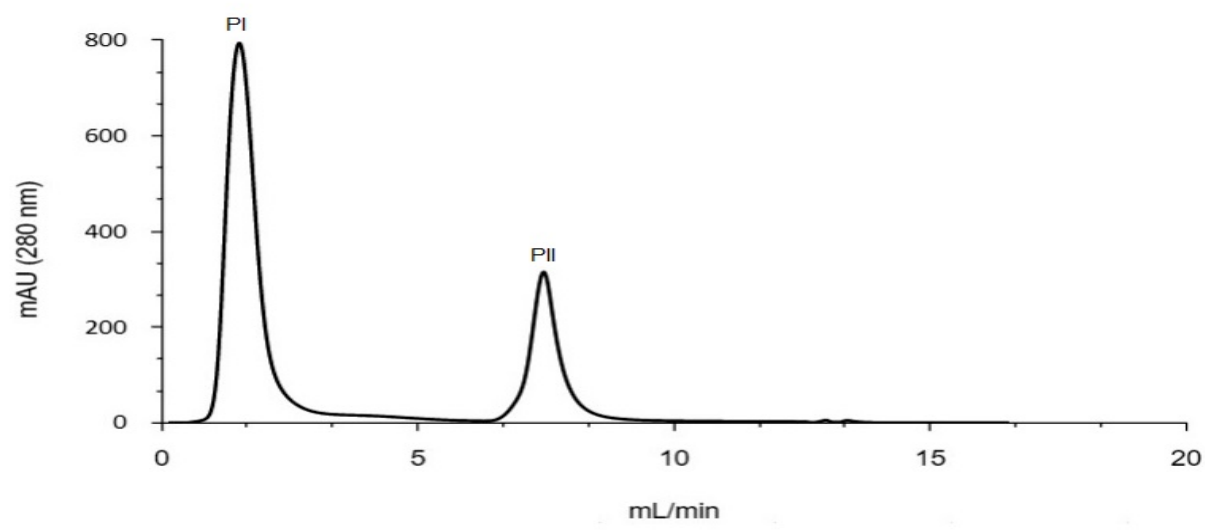

Figure 1. Chromatographic profile of $C$. vulgaris cell extract applied HiTrapTM DEAE FF column; PI eluted with Tris- $\mathrm{HCl} \mathrm{pH} 7.5$ with $0.15 \mathrm{M} \mathrm{NaCl}$; PII eluted with Tris- $\mathrm{HCl} \mathrm{pH} 7.5$ with $1 \mathrm{M} \mathrm{NaCl}$. 


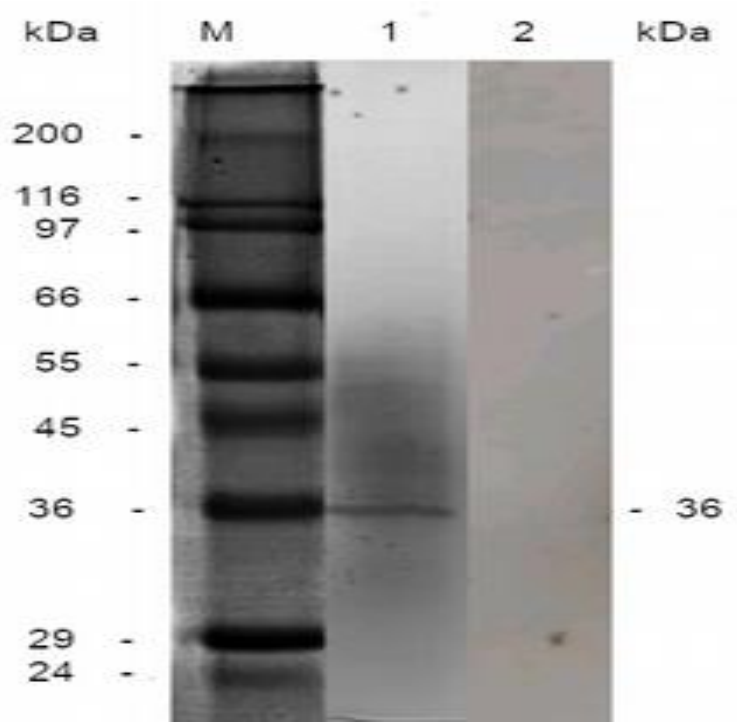

Figure 2. SDS-PAGE analysis of the fractions of purified proteins from $C$. vulgaris cell extract using DEAE ion-exchange chromatography column. M: Molecular weight marker; 1 : Purified $0.15 \mathrm{M} \mathrm{NaCl}$; 2: Purified 1.0 $\mathrm{M} \mathrm{NaCl}$.

Over the years, different bioproducts have been used for medicinal purposes. Microalgae represent a promising and natural source for producing biochemically active substances such as proteins, pigments, lipids, and other compounds. Metabolite variations are related to the diversity of defense mechanisms that result in various compounds produced by various metabolic pathways, resulting in various beneficial biological activities such as antioxidant, anti-inflammatory, antimicrobial and immunomodulatory [31, 32].

The terpenes and lectins in $C$. vulgaris extract are described as antioxidant, antiinflammatory, immunomodulatory agents [28, 30, 33]. The synergistic effects of these compounds may help in healing activity. There are few documented studies using microalgae for wound healing, and the lack of studies does not provide sufficient support to understand the mechanism of activity of this extract.

\subsection{Gel characteristics.}

Macroscopic characteristics of the gel formulation showed green color, a smooth texture, slightly turbid and homogeneous, without signs of instability and characteristic odor attributed to microalgae extract. The physiological $\mathrm{pH}$ of the open wounds is 7.1 to 7.3 . It is required that the $\mathrm{pH}$ value of the formulation should remain in this range [34]. The gel showed $\mathrm{pH}$ values of $7.09 \pm 0.07$. In our previous study, no skin irritation in mice was observed due to gel application for twelve days of study [7].

The bioavailability efficacy of the gel depends on its ability to spread when applied to the skin $[35,36]$. The spreadability of the formulation was high $(4.5-6.9 \mathrm{~cm})$ by having a higher spread in a short time (Figure 3). These results indicate that the spreadability achieved by the formulation leaves a thinner film and uniform on the skin. In other words, less force will be required to spread the product in inflamed, hairy, or oily areas, such as chronic injuries. This result is clinically important in patient compliance once these injured areas are painful and sensitive [35, 37]. 


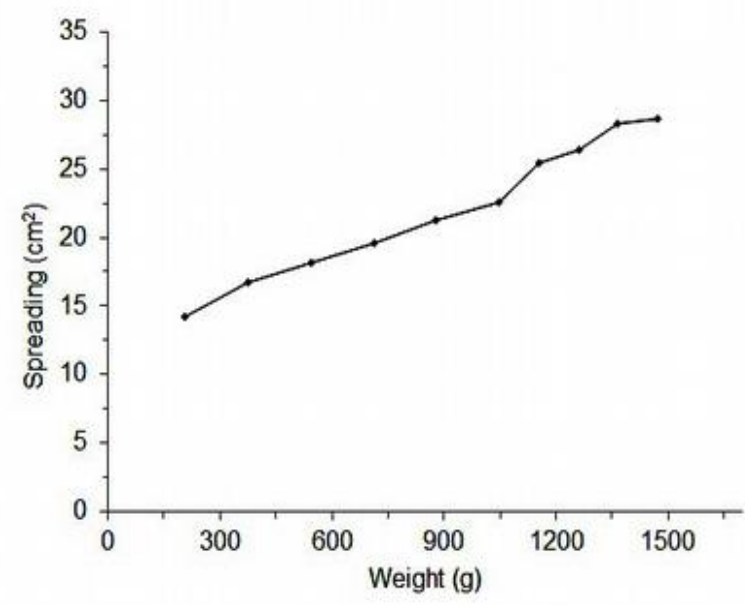

Figure 3. Spreadability of the formulation containing $C$. vulgaris cell extract.

Rheological tests were performed to evaluate how microalgae extract influences the viscosity behavior of the carbopol vehicle. Figure 4 shows the behavior of the formulation, which had a viscosity tested ten times with 10 to $100 \mathrm{rpm}$ and 100 to $10 \mathrm{rpm}$. Regarding the rheological evaluation, the formulation presented non-Newtonian pseudoplastic flow, characteristic of semisolids [38].

Furthermore, this gel was characterized by thixotropy. This flow behavior exhibited by topical semisolids is desirable, as it means that the formulation can be applied to the thin layers of the skin and spread over the applied area. The hydrogel viscosity plays an essential role in the delivery of the molecules [35].

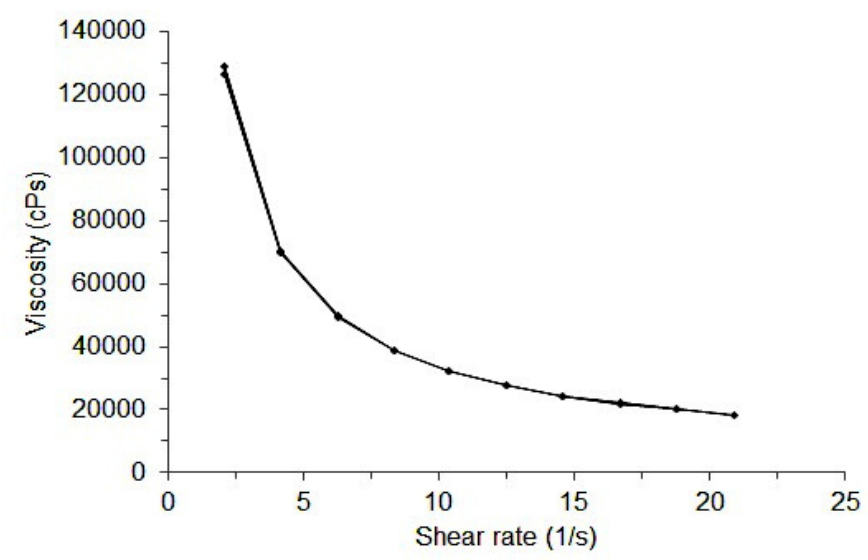

Figure 4. Effect of shear rate on the viscosity of the formulation containing $C$. vulgaris cell extract.

Worldwide, there is an increase in the development of topical formulations, such as gels and emulsions, for the repair of wounds [38]. Hydrogels should exhibit basic features, such as capacity spreading, drug compatibility, safety, low toxicity, and shelf stability, biodegradability, and other biofunctionalities. A hydrogel should be biodegradable for tissue engineering as they function as a temporary extracellular matrix until organized new tissue, while bioactivity is essential for guiding cell behavior, such as cell proliferation and differentiation [39].

\subsection{FTIR spectroscopy.}

FT-IR spectrum of the extract of C. vulgaris at $3187 \mathrm{~cm}^{-1}$ shows the presence of $\mathrm{OH}$ stretching, indicates carboxylic acids (Figure 5A). The cell extract exhibited absorption bands 
in the region of $2954 \mathrm{~cm}^{-1}$ due to $\mathrm{C}-\mathrm{H}$ stretching vibration, indicates terpenes [40] confirming the results achieved by qualitative analysis. The band $1629 \mathrm{~cm}^{-1}$ is assigned to amine stretching [41], indicating protein contents. The observed sharp peak at $1553 \mathrm{~cm}^{-1}$ is for $\mathrm{N}-\mathrm{O}$ stretching. The peak at $1401 \mathrm{~cm}^{-1}$ was the joint contribution of the vibration of $\mathrm{OH}$ and $\mathrm{C}-\mathrm{H}$ [42]. The extract showed a vibration in the region at $1035 \mathrm{~cm}^{-1}$ related to carbohydrates[43].

C. vulgaris contains several carbohydrates, including $\beta-1,3$ glucan, a modifier of the response biological with an activity immunostimulator and a free-radical scavenger [44]. Studies report the ability of $\beta$-1,3-glucan to activate the innate immune response with effects also on adaptive immunity, inducing humoral immune responses, increasing the antimicrobial activity of mononuclear and neutrophil cells and macrophage response [45]. Based on these results of the FTIR analysis, $C$. vulgaris cell extract composition may be correlated with the healing activity.

FTIR analysis was used to test for any chemical or physical interactions between $C$. vulgaris extract and carbopol hydrogel. The carbopol hydrogel exhibited a stretching vibration peak at $3332 \mathrm{~cm}^{-1}$ associated $(-\mathrm{OH})$ free hydroxyl group. The typical band vibration from $\mathrm{C}=\mathrm{O}$ is detected at $1638 \mathrm{~cm}^{-1}$ (Figure 5B). All three peaks are visible in the spectra of formulation (Figure 5C), suggesting the absence of chemical interaction between the microalgae cell extract and carbopol hydrogel, as well as a physical mixture of both [46, 47].

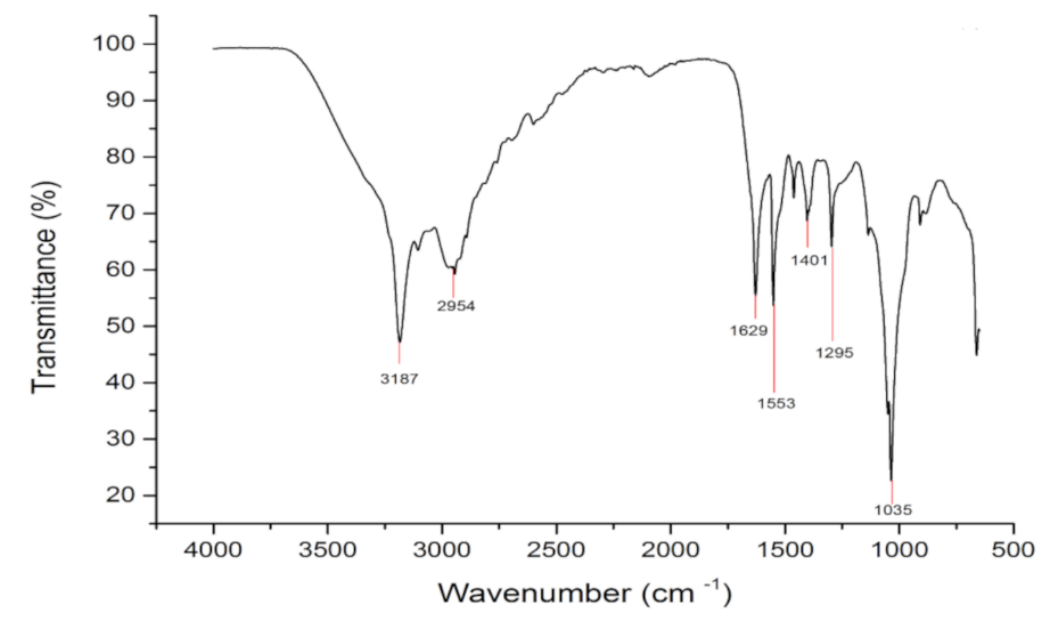

B

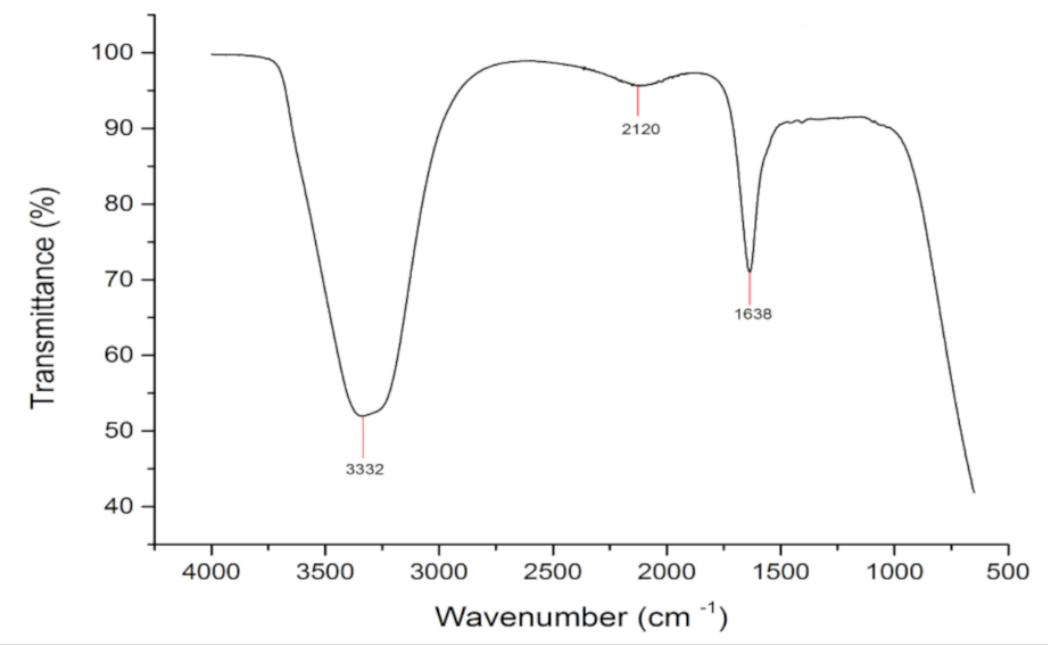


C

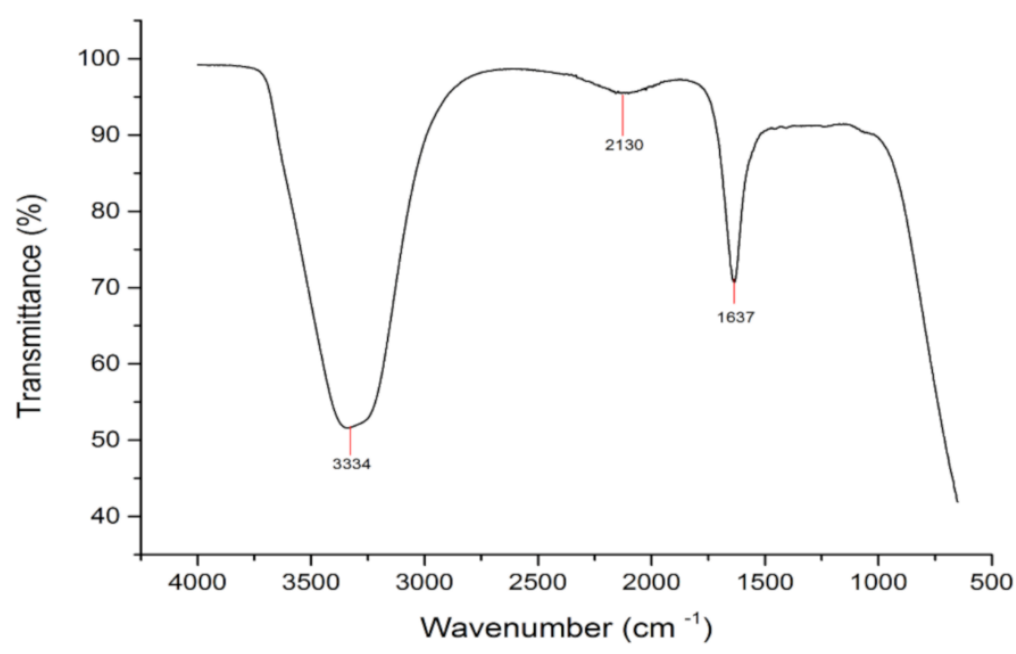

Figure 5. FT-IR spectra of: (A) cell extract of C. vulgaris; (B) carbopol-940; (C) formulation.

\subsection{Thermogravimetric analysis.}

Figure 6 shows the TGA diagram of the cell extract, methylisothiazolinone, and carbopol-940. According to the TGA curve, decomposition of the cell extract was observed at a temperature of $239.55{ }^{\circ} \mathrm{C}$ with a weight loss $23.56 \%$. The degradation of methylisothiazolinone was $94.69 \%$; the curve shows that the quality decreased rapidly up to $167.11^{\circ} \mathrm{C}$, mainly via water evaporation. Carbopol-940 was more stable than cell extract and methylisothiazolinone, with a mass loss of $19.39 \%$ at $315.09 \%$. Weight loss between Carbopol-940 and cell extract was 9.07\%, appeared at a temperature of $207.09{ }^{\circ} \mathrm{C}$. Due to a significant amount of moisture, until $151.00{ }^{\circ} \mathrm{C}$, weight loss is noticeable between cell extract and methylisothiazolinone.

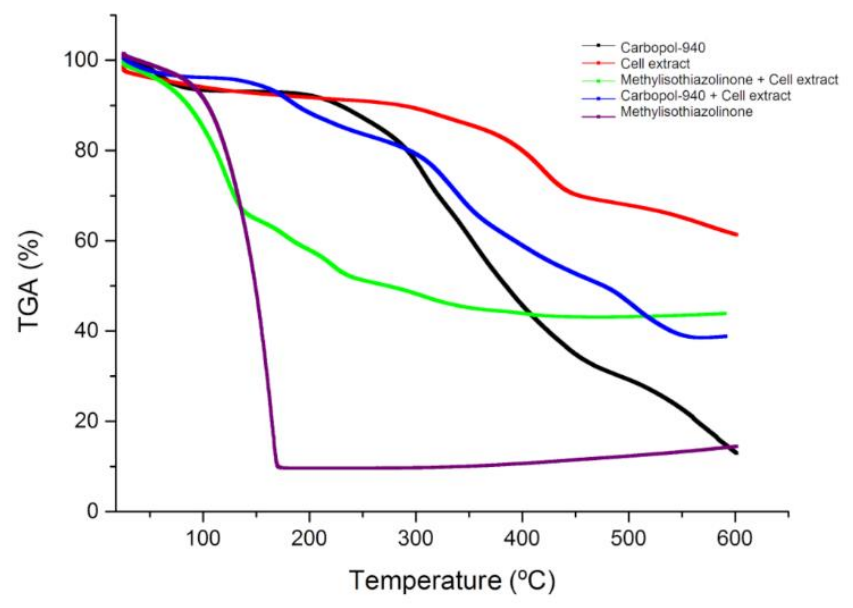

Figure 6. TGA of cell extract, methylisothiazolinone and carbopol-940.

Since the proposed formulation is intended to be used to deliver biomolecules from the microalgae extract and the release process is normally carried out at physiological temperature $37^{\circ} \mathrm{C}$, the formulation is totally stable at room temperature, which varies between 27 and 38 ${ }^{\circ} \mathrm{C}[48]$. 


\section{Conclusions}

C. vulgaris extract has a mixture of proteins, carbohydrates, and terpenes that can have a synergistic effect on epithelial re-epithelialization and wound healing. $C$. vulgaris extract was integrated into the carbopol to obtain a semisolid, and the analysis of thermal behavior showed stability at room temperature. The formulation showed smooth texture, viscosity, and spreadability that are appropriate for semisolid. The formulation show $\mathrm{pH}$ would not produce irritation and can promote the permeation of biomolecules in the skin. The results obtained will provide parameters for the production of inputs in the pharmaceutical industry, as well as for the quality control of intermediates and the finished product based on C. vulgaris.

\section{Funding}

This research received no external funding.

\section{Acknowledgments}

The authors gratefully acknowledge Fundação de Amparo à Ciência e Tecnologia do Estado de Pernambuco (FACEPE, APQ-0252-5.07/14, IBPG-0489-5.05/17, BIC-1161-5.05/18) and Centro de Apoio à Pesquisa (CENAPesq) from the Universidade Federal Rural de Pernambuco. This study was financed in part by Coordenação de Aperfeiçoamento de Pessoal de Nível Superior (CAPES) - Finance Code 001.

\section{Conflicts of Interest}

The authors declare no conflict of interest.

\section{References}

1. Sathasivam, R.; Radhakrishnan, R.; Hashem, A.; Abd_Allah, EF. Microalgae metabolites: A rich source for food and medicine. Saudi J Biol Sci 2019, 26, 709-722, https://doi.org/10.1016/j.sjbs.2017.11.003.

2. Yarkent, C.; Gürlek, C.; Oncel, S.S. Potential of microalgal compounds in trending natural cosmetics: A review. Sustain Chem Pharm 2020, 17, 100304, https://doi.org/10.1016/j.scp.2020.100304.

3. Albaayit, S.F.A.; Abba, Y.; Rasedee, A.; Abdullah, N. Effect of Clausena excavata Burm. f. (Rutaceae) leaf extract on wound healing and antioxidant activity in rats. Drug Des Devel. Ther 2015, 9, 3507-3518, https://doi.org/10.2147/DDDT.S84770.

4. Chu, C.Y.; Huang, R.; Lin, L.P. Purification and characterization of a novel haemagglutinin from Chlorella pyrenoidosa. J Industrial Microbiol Biotechnol 2006 , 33, 967-973, https://doi.org/10.1007/s10295-0060145-9.

5. Dantas, D.M.M.; Costa, R.M.P.B.; Carneiro-Da-Cunha, M.G.; Galvez, A.O.; Drummond, A.R.; Bezerra, R.S. Bioproduction, Antimicrobial and Antioxidant Activities of Compounds from Chlorella vulgaris. Research \& Reviews: J Bot Sci 2015, 4.

6. El-fayoumy, E.A.; Shanab, S.M.M.; Gaballa, H.S.; Tantawy, M.A.; Shalabyet, E.A. Evaluation of antioxidant and anticancer activity of crude extract and different fractions of Chlorella vulgaris axenic culture grown under various concentrations of copper ions. BMC Complement Med Ther 2021, 21, 51, https://doi.org/10.1186/s12906-020-03194-x.

7. Melo, R.G.; Andrade, A.F.; Bezerra, R.P.; Marques, D.A.V.; Silva, V.A.; Paz, S.T.; Lima-Filho, J.L.; Porto, A.L.F. Hydrogel-based Chlorella vulgaris extracts: a new topical formulation for wound healing treatment. J appl phycol 2019, 31, 3653-3663, https://doi.org/10.1007/s10811-019-01837-2.

8. Pan, H.; Fan, Daidi.; Cao, W.; Zhu, C.; Duan, Z.; Fu, R.; Li, X.; Ma, X. Preparation and Characterization of Breathable Hemostatic Hydrogel Dressings and Determination of Their Effects on Full-Thickness Defects. Polymers 2017, 9, 727, https://doi.org/10.3390/polym9120727.

9. Shelke, U.; Mahajan, A.A. Review on: An ointment. Int J Pharm Pharma Resear 2015, 4, 170-192. 
10. Boateng, J.; Catanzano, O. Advanced Therapeutic Dressings for Effective Wound Healing-A Review. J PharmSci 2015, 104, 3653-3680, https://doi.org/10.1002/jps.24610.

11. Nho, Y.C.; Park, J.S.; Lim, Y.M. Preparation of hydrogel by radiation for the healing of diabetic ulcer. Radiat. Phys. Chem 2014, 94, 176-180, https://doi.org/10.1016/j.radphyschem.2013.07.021.

12. Gianeti, M.D.; Gaspar, L.R.; Camargo, F.B.J.; Campos, P.M.B.G.M. Benefits of combinations of vitamin A, $\mathrm{C}$ and $\mathrm{E}$ derivatives in the stability of cosmetic formulations. Molecules 2012, 17, 2219-2230, https://doi.org/10.3390/molecules17022219.

13. Toledo, A.C.O.; Hirata, L.L.; Buffon, M.C.M.; Miguel, M.D.; Miguel, O.G. Fitoterápicos: uma abordagem farmacoténica, Revista Lecta, Bragança Paulista 2003, 21, 7-13.

14. Bischoff, H.W.; Bold, H.C. Psychological Studies. IV. Some Algae from Enchanted Rock and Related Algae Species. University of Texas 1963, 6318, 1-95.

15. Silva, P.E.C.; Souza, F.A.Z.; Barros, R.C.; Viana-Marques, D.A.; Porto, A.L.F.; Bezerra, R.P. Enhanced production of fibrinolytic protease from microalgae Chlorella vulgaris using glycerol and corn steep liquor as nutrient. J. Microbiol. Res 2017, 1, 9-19, https://doi.org/10.36959/958/564.

16. Savithramma, N.; Rao, M.L.; Rukmini, K.; Devi, P.S. Antimicrobial activity of silver nanoparticles synthesized by using medicinal plants. Int J Chem Tech Resear 2011, 3, 1394-1402.

17. Singleton, V.L.; Orthofer. R.; Lamuela-Raventos, R.M. Analysis of total phenols and other oxidation substrates and antioxidants by means of Folin-Ciocalteu reagent. Methods Enzymol 1999, 299, 152-178, https://doi.org/10.1016/S0076-6879(99)99017-1.

18. Laemmli, U.K. Cleavage of structural proteins during the assembly of the head of bacteriophage T4. Nature 1970, 227, 680-685, https://doi.org/10.1038/227680a0.

19. Correia, M.T.S.; Coelho, L.C.B.B. Purification of a glucose/mannose specific lectin, isoform 1, from seeds of Cratylia mollis mart (Camaratu Bean). Appl Biochem Biotechnol 1995, 55, 261-273, https://doi.org/10.1007/BF02786865.

20. Porto, A.L.F.; Bezerra, R.P.; Andrade, A.F.; Melo, R.G.; Herculano, P.N.; Silva-Junior, V.A.; Ribeiro, M.H.M.L.; Lima-Filho, J.L.; et al. Formulação tópica em gel com atividade cicatrizante contendo extrato de microalga. Deposit number: BR 1020180772120, Dez. 272018.

21. Knorst, M.T. Desenvolvimento tecnológico de forma farmacêutica plástica contendo extrato concentrado de Achyrocline satureioides. Lam. DC. Compositae. (Marcela). Dissertação de Mestrado. Faculdade de Farmácia. Universidade Federal do Rio Grande do Sul 1991.

22. Jayshree, A.; Jayashree, S.; Thangaraju, N. Chlorella vulgaris and Chlamydomonas reinhardtii: effective antioxidant, antibacterial and anticancer mediators. Indian J Pharmaceut Sci 2016, 78, 575-81, https://doi.org/10.4172/pharmaceutical-sciences.1000155.

23. Lasram, S.; Zemni, H.; Hamdi, Z.; Chenenaoui, S.; Houissa, H.; Tounsi, M.S.; Ghorbel, A. Antifungal and antiaflatoxinogenic activities of Carum carvi L., Coriandrum sativum L. seed essential oils and their major terpene component against Aspergillus flavus. Ind Crops Produ 2019, 134, 11-18, https://doi.org/10.1016/j.indcrop.2019.03.037.

24. Sumaya, S.S.; Murugan, K. Phytochemical screening, RP-HPLC and FTIR Analysis of Kappaphycus alvarezii (Doty) Doty EX P.C Silva: Macro red algae. J Pharm Phytochem 2017, 6, 325-330.

25. Sousa, F.D.; Vasconcelos, P.D.; Silva, A.F.B.; Mota, E.F.; Tomé, A.R.; Mendes, F.R.S.; Gomes, A.M.M.; Abraham, D.J.; Shiwen, X.; Owen, J.S.; Lourenzoni, M.R. Hydrogel and membrane scaffold formulations of Frutalin (breadfruit lectin) within a polysaccharide galactomannan matrix have potential for wound healing. Int J Biol Macromol. 2019, 121, 429-442, https://doi.org/10.1016/j.ijbiomac.2018.10.050.

26. Wanderley, M.C.A.; Duarte-Neto, J.M.W.; Andrade, A.F.; Melo, R.G.; Viana-Marques, D.A.; Bezerra, R.P.; Porto, A.L.F. First report on Chlorella vulgaris collagenase production and purification by aqueous twophase system. Sustain. Chem. Pharm 2020, 15, 5100202, https://doi.org/10.1016/j.scp.2019.100202.

27. Abood, A.; Salman, A.M.M.; Abdelfattah, A.M.; El-Hakim, A.E.; Abdel-Aty, A.M.; Hashem, A.M. Purification and characterization of a new thermophilic collagenase from Nocardiopsis dassonvillei NRC2aza and its application in wound healing. Int $J$ Biol Macromol 2018, 116, 801-8110, https://doi.org/10.1016/j.ijbiomac.2018.05.030.

28. Araujo, L.C.C.; Aguiar, J.S.; Napoleao, T.H.; Mota, F.V.B.; Barros, A.L.S.; Moura, M.C.; Coriolano, M.C.; Coelho, L.C.B.B.; Silva, T.G.; Paiva, P.M.G. Evaluation of cytotoxic and anti-inflammatory activities of extracts and lectins from Moringa oleifera SEEDS. PLOS ONE 2013, 8, 81973, https://doi.org/10.1371/journal.pone.0081973. 
29. Coriolano, M.C.; Melo, C.M.L.; Silva, F.D.O.; Schirato, G.V.; Porto, C.S.; Santos, P.J.P.; Correia, M.T.S.; Porto, A.L.F.; Carneiro-Leao, A.M.A.; Coelho, L.C.B.B. Parkia pendula Seed Lectin: Potential Use to Treat Cutaneous Wounds in Healthy and Immunocompromised Mice. Appl Biochem Biotechnol 2014, 172, 26822693, https://doi.org/10.1007/s12010-013-0692-2.

30. Kim, S.Y.; Park, B.J.; Lee, Y.; Park, N.J.; Park, K.M.; Hwang, Y.; Park, K.D. Human hair keratin-based hydrogels as dynamic matrices for facilitating wound healing. J Indust Eng Chem 2019, 73, 142-151, https://doi.org/10.1016/j.jiec.2019.01.017.

31. Bari, E.; Arciola, C.R.; Vigani, B.; Crivelli, B.; Moro, P.; Marrubini, G.; Sorrenti, M.; Catenacc, L.; Bruni, G.; Chlapanidas, T.; Lucarelli, E.; Perteghella, S.; Torre, ML. In Vitro Effectiveness of Microspheres Based on Silk Sericin and Chlorella vulgaris or Arthrospira platensis for Wound Healing Applications. Materials 2017, 10, 983, https://doi.org/10.3390/ma10090983.

32. 32. Qi, J.; Kim, S.M. Characterization and immunomodulatory activities of polysaccharides extracted from green alga Chlorella ellipsoidea. Int $J$ Biol Macromol 2016, 9, 106-114, https://doi.org/0.1016/j.ijbiomac.2016.11.039.

33. Patil, S.P.; Kumbhar, S.T. Evaluation of terpene-rich extract of Lantana camara L. leaves for antimicrobial activity against mycobacteria using Resazurin Microtiter Assay (REMA). Beni-Suef University J Basic Appl Sci 2018, 7, 511-515, https://doi.org/10.1016/j.bjbas.2018.06.002.

34. Dandasi, J.C.D.; Jayaprakash, J.S.; Kulkarni, P.K.; Akhila, A.R.; Namratha, S. Formulation and evaluation of different topical dosage forms for wound healing properties. Int J Resear Pharm Sci 2020, 11, 730-746, https://doi.org/10.26452/ijrps.v11i1.1886.

35. Saryanti, D.; Zulfa, I.N. Optimization Carbopol And Glycerol As Basis Of Hand Gel Antiseptics Extract Ethanol Ceremai Leaf (Phyllantus Acidus (L.) Skeels) With Simplex Lattice Design. J Pharm Sci Clin Res 2017, 2, 35-47, https://doi.org/10.20961/jpscr.v2i1.5238.

36. Rigo, L.A.; Silva, C.R.; Oliveira, S.M.; Cabreira, T.N.; Bona da Silva, C.; Ferreira, J.; Beck, R.C. Nanoencapsulation of rice bran oil increases its protective effects against UVB radiation-induced skin injury in mice. Eur J Pharm Biopharm 2015, 93, 11-17, https://doi.org/10.1016/j.ejpb.2015.03.020.

37. Almeida, J.S.; Benvegnú, D.M.; Boufleur, N.; Reckziegel, P.; Barcelos, R.C.S.; Coradini, K.; Carvalho, L.M.; Burger, M.E.; Beck, R.C.R. Hydrogels containing rutin intended for cutaneous administration: efficacy in wound healing in rats. Drug Dev Ind Pharm 2011, 38, 792-799, https://doi.org/10.3109/03639045.2011.628676.

38. Pegoraro, N.S.; Camponogara, C.; Gehrce, M.; Giuliani, L.M.; Silva, D.T.; Maurer, L.H.; Dias, P.; Emanuelli, T.; Cruz, L.; Oliveira, S.M. Oleic acid-containing semisolid dosage forms exhibit in vivo anti-inflammatory effect via glucocorticoid receptor in a UVB radiation-induced skin inflammation model. Inflammopharmacology 2019, 28, 773-786, https://doi.org/10.1007/s10787-019-00675-5.

39. Jin, R.; Dijkstra, P.J. Hydrogels for tissue engineering applications. Biomedical applications of hydrogels Handbook. Springer New York, New York, NY 2010, 215-225.

40. Majumder, A.; Singh, A.; Goyal, A. Application of response surface methodology for glucan production from Leuconostoc dextranicum and its structural characterization, Carbohydr. Polym 2009, 75, 150-156, https://doi.org/10.1016/j.carbpol.2008.07.014.

41. Yokoi, H.; Aratake, T.; Hirose, J.; Hayashi, S.; Takasaki, Y. Chitosan production from shochu distillery wastewater by Funguses. J. Ferment. Bioeng 1998, 85, 246-249, https://doi.org/10.1016/S0922338X(97)86777-3.

42. Qian, F.; Cui, F.; Ding, J.; Tang, C.; Yin, C. Chitosan graft copolymer nanoparticles for oral protein drug delivery: Preparation and characterization. Biomacromolecules 2006, 7, 2722-2727, https://doi.org/10.1021/bm060065f.

43. Bramhachari, P.V.; Dubey, S.K. Isolation and characterization of exopolysaccharide produced by Vibrio harveyi strain VB23. Lett. Appl. Microbiol. 2006, 43, 571-577, https://doi.org/10.1111/j.1472765X.2006.01967.x.

44. Wang, H.M.; Pan, J.L.; Chen, C.Y.; Chiu, C.C.; Yang, M.H.; Chang, H.W.; Chang, J.S. Identification of antilung cancer extract from Chlorella vulgaris $\mathrm{C}-\mathrm{C}$ by antioxidant property using supercritical carbon dioxide extraction. Proc Biochem 2010, 45, 1865-1872, https://doi.org/10.1016/j.procbio.2010.05.023.

45. Chanput, W.; Reitsma, M.; Kleinjans, L.; Mes, J.J.; Savelkoul, H.F.; Wichers, H.J. B-glucans are involved in immune-modulation of THP-1 macrophages. Mol Nutr Food Res 2012, 56, 822-833, https://doi.org/10.1002/mnfr.201100715. 
46. Singh, V.K.; Anis, A.; Banerjee, I.; Pramanik, K.; Bhattacharya, M.K.; Pal, K. Preparation and characterization of novel carbopol based bigels for topical delivery of metronidazole for the treatment of bacterial vaginosis. Mater Sci Eng C Mater Biol Appl 2012, 44, 151-158, https://doi.org/10.1016/j.msec.2014.08.026.

47. Bangarakodi, K.; Rajamanickam, D.; Jeyaraman, A.; Srinivasan, B. Preparation and Characterization of Wound Dressings Incorporated with Curcumin, Povidone Iodine, and Silver Sulphadiazine. Lett Appl NanoBioSci 2021, 10, 1748-1759, https://doi.org/10.33263/LIANBS101.17481759.

48. Thurmer, M.B.; Diehl, C.E.; Brum, F.J.B.; Santos, L.A. Preparation and Characterization of Hydrogels with Potential for Use as Biomaterials. Materials Resear 2014, 17, 109-113, https://doi.org/10.1590/15161439.223613. 